\title{
Implementation of animal welfare in tiger sanctuary, Barumun Nagari Wildlife Sanctuary, North Sumatra, Indonesia
}

\author{
RONNA SAAB ${ }^{1, \boldsymbol{v}}$, PAHRIAN GANAWIRA SIREGAR ${ }^{2}$, TATANG MITRA SETIA ${ }^{3}$ \\ ${ }^{1}$ Biology Graduate Program, Department of Biology, Universitas Nasional. Jl. Sawo Manila, Pejaten, Pasar Minggu, Jakarta Selatan 12550, Jakarta, \\ Indonesia. Tel.: +62-021-7806700, `email: ronnasaab@gmail.com \\ ${ }^{2}$ School of Environmental Science, Multidisciplinary Graduate Program, Universitas Indonesia. Jl. Salemba Raya, Jakarta Pusat 10430, Indonesia \\ ${ }^{3}$ Department of Biology, Graduate School, Universitas Nasional. Jl. Sawo Manila, Pejaten, Pasar Minggu, Jakarta Selatan 12550, Jakarta, Indonesia
}

Manuscript received: 7 June 2019. Revision accepted: 3 September 2019.

\begin{abstract}
Saab R, Siregar PG, Tatang Mitra Setia TM. 2019. Implementation of animal welfare in tiger sanctuary, Barumun Nagari Wildlife Sanctuary, North Sumatra, Indonesia. Biodiversitas 20: 2790-2795. The accelerated growth in the development of economic and social infrastructure has drastically diminished the population of Sumatran tiger (Panthera tigris sumatrae) and its habitat. As a result, conflicts between tigers and humans are increasing rapidly in recent years. The wild tigers in conflict, such as those that attack humans and livestock, are usually killed or captured, while those who cannot return to the forest due to injury or illness are then translocated to the zoo. The increasing number of human and tiger conflicts raises the need for special facilities, such as sanctuaries, to recover the condition of the tigers, before they are released to the wild. This study aimed to examine the aspects of welfare management and assess the level of welfare of the tigers kept in the sanctuary at the Barumun Nagari Wildlife Sanctuary (BNWS) in North Sumatra, Indonesia. The study was carried out from March to April 2019, while data collection was carried out by literature studies, field observation on implementation of five animal welfare parameters, and self-assessment by the manager of the sanctuary. The results showed that, on a score from 1 to 5, the animal welfare parameter scores were 4.88 (freedom from hunger and thirst), 4.81 (freedom to express natural behavior), 4.79 (freedom from discomfort), 3.81 (freedom from fear and distress) and 3.69 (freedom from pain, injuries, and diseases). The total achievement implementation value of animal welfare in BNWS was 89.13, or very good. However, some improvements still have to be made by the sanctuary manager to enhance the animal welfare of tigers in BNWS.
\end{abstract}

Keywords: Animal welfare, Barumun, sanctuary, tiger

\section{INTRODUCTION}

Animal welfare is a physical condition and animal psychology as an effort to adapt to their environment (Triastuti 2015). Animal welfare is often defined as an animal's ability to cope with certain situations or environments (Fraser and Broom 1990). Concern for animal welfare has been growing in the last 15-20 years. Nowadays, zoos and sanctuaries throughout the world are very committed to implementing animal welfare in their management (Mellor et al. 2015).

The population of Sumatran tiger (Panthera tigris sumatrae) and its habitat are drastically diminishing due to the accelerated growth of economic and social infrastructure (Sanderson et al. 2006). This situation leads to a rapid increase in conflicts between tigers and humans in recent years. According to Rudijanta and Sugardjito (2009), human-tiger conflicts contribute substantially to the continuing decline of the wild tiger population in Sumatra. According to the data from 2001-2016, there were 1,065 cases of human-tiger conflicts in Sumatra (Kartika 2017). These conflicts often result in tragic ends, including the death of female tiger during her pregnancy due to a snare trap, in Muara Lembu, Kuantan Singingi District, Riau Province in September 2018 (BBC 2018)

A common conflict between humans and wildlife in Sumatra is livestock hunting by tigers (Nyhus \& Tilson
2004) which often leads to both tiger and human casualties. In North Sumatra, according to the record of the Centre for Natural Resources Conservation of North Sumatra, between 2007 and 2018, there were 57 cases of humantiger conflict. The conflicts resulted in 5 people being killed, 2 people injured and dozens of livestock devoured by tigers. On the other hand, it also resulted in the death of 6 tigers and amputation of a tiger's leg (BBKSDA North Sumatra 2019).

The wild tigers in conflicts, such as those that attack humans and livestock, are usually killed or captured. The tigers being caught are then taken to the nearest zoos, while the impact on their population in nature is unknown. Meanwhile, ex-situ conservation policies implemented so far have not been able to address the in-situ conservation issues that we face today (Soehartono et al. 2007).

The increasing number of human and tiger conflict has led to the increasing numbers of mortality, capture, and removal of tigers from their natural habitats (Goodrich et al. 2010), and raised the need for special facilities, such as sanctuaries, to recover the condition of the tigers, before they are released to their habitat.

The survival of tigers kept in a sanctuary should be a major concern. Therefore, proper management which is able to support their lives, even though they are kept in an ex-situ area, is highly required (OIE2009). Thus far, we have a lack of information on animal welfare management 
in Indonesia. In fact, the availability of information on animal welfare is important to be studied further, as a reference for improving future management. Moreover, up to now, there are no clear policies or guidelines provided regarding the management of sanctuaries in Indonesia, so the sanctuary management should develop their own guideline.

This study aimed to examine the aspects of welfare management, to assess the level of welfare of Sumatran tigers kept in the sanctuary at the Barumun Nagari Wildlife Sanctuary (BNWS), and to recommend several actions to improve the animal welfare in BNWS.

\section{MATERIALS AND METHODS}

The study was carried out from March to April 2019 in Barumun Nagari Wildlife Sanctuary (BNWS), situated at North Padang Lawas District, North Sumatra Province, Indonesia. BNWS is now a temporary 'home' for Monang, Gadis and her two cubs born at this facility. Monang is a male tiger that was translocated from the forest around the Aek Nauli Education Forest, in Simalungun District in May 2017. Meanwhile, Gadis, is the female tiger which had conflict with humans in Batang Gadis National Park and one of her legs must be amputated due to severe injury from trapping. Gadis was translocated to BNWS in November 2016. The two cubs were born on December 12,
2018. At present, Monang is placed separately from the two cubs to avoid infanticide.

The collection of data on animal welfare was carried out by literature studies, observation, and self-assessment by the manager of the sanctuary. We observed how the sanctuary management applied five parameters for animal welfare (The Five Freedoms) according to the Farm Animal Welfare Council (1992), namely (i) freedom from thirst and hunger, (ii) freedom from discomfort, (iii) freedom from pain, injury and disease, (iv) freedom to express normal behaviour, and (v) freedom from fear and distress.

The animal welfare was assessed based on the assessment guidelines published by The Directorate General of Forest Protection and Nature Conservation (PHKA) Regulation Number P.6/IV-SET/2011 on Guideline on the Assessment of Conservation Institution, by filling in the evaluation table on animal welfare. Due to the absence of specific assessment guidelines for sanctuary, we deployed the assessment tool for zoo and animal park within this regulation for this study. The assessment grades for each variable were bad (value: 1), not good (value: 2), fair (value:3), good (value: 4), and very good/satisfying (value: 5). In the assessment, we also adopted the international standard for felid sanctuary (GFAS2018) and tiger care published by the Association of Zoo and Aquarium (AZA2016).

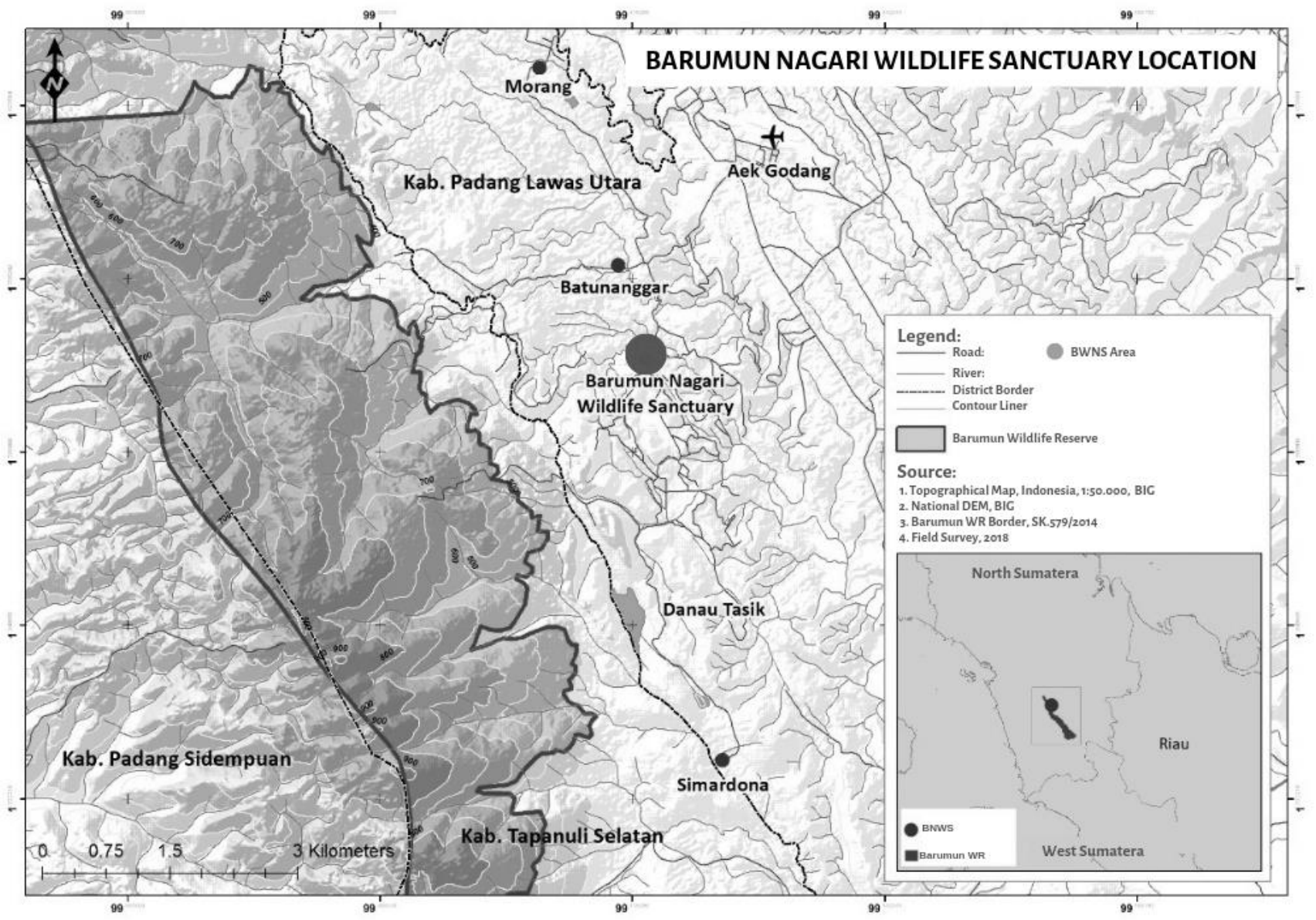

Figure 1. Study site in Barumun Nagari Wildlife Sanctuary (BNWS), North Padang Lawas District, North Sumatra Province, Indonesia 
To ensure the objectivity in collecting data, in this study, the managers of the sanctuary were also invited to do their assessment, so that the results of animal welfare assessments were not only derived from the perspective of the researcher. The final scores of assessment were the average of the two assessment.

The weight of every aspect was calculated based on its importance in fulfilling tiger welfare. The total value of each animal welfare principle was entered into the scoring column to get the weight value of each parameter (Table 1). The weighted values for each parameter were obtained by multiplying the score with the weights.

Then, the Implementation Achievement (IA) of animal welfare was calculated with the following formula:

$$
\mathrm{IA}=\frac{\Sigma \text { Value of IPW }}{\Sigma \text { AWP }}
$$

Note:

IPW: Individual Parameter Weighted Value

AWP: Animal Welfare Parameter

The final results of achievement implementation of animal welfare were classified as indicated in Table 2:

Table 1. The weight of animal welfare assessment at Barumun Nagari Wildlife Sanctuary, North Sumatra, Indonesia (PHKA2011)

\begin{tabular}{lccc}
\hline \multicolumn{1}{c}{ Animal Welfare Parameters } & Weight & Score & $\begin{array}{c}\text { Weighted } \\
\text { value }\end{array}$ \\
\hline Freedom from hunger and thirst & 30 & $1-5$ & $30-150$ \\
Freedom from discomfort & 20 & $1-5$ & $20-100$ \\
$\begin{array}{l}\text { Freedom from pain, injuries, and } \\
\text { diseases }\end{array}$ & 20 & $1-5$ & $20-100$ \\
$\begin{array}{l}\text { Freedom to express natural } \\
\text { behavior }\end{array}$ & 15 & $1-5$ & $15-75$ \\
Freedom from fear and distress & 15 & $1-5$ & $15-75$ \\
\hline
\end{tabular}

Table 2. The implementation achievement on animal welfare (PHKA 2011)

\begin{tabular}{lc}
\hline Assessment classification & Implementation achievement \\
\hline Excellent & $80-100$ \\
Good & $70-79$ \\
Fair & $60-69$ \\
Need assistance & $<60$ \\
\hline
\end{tabular}

\section{RESULTS AND DISCUSSION}

The total scores of animal welfare in BNWS were presented in a Radar Diagram below (Figure 1). The diagram shows that the highest score was obtained for the parameter of 'freedom from hunger and thirst' (4.88). The management of 'freedom from hunger and thirst' aspect can be assessed from the quantity and quality of feed, cleanliness of feed, type of feeding and time of feeding.

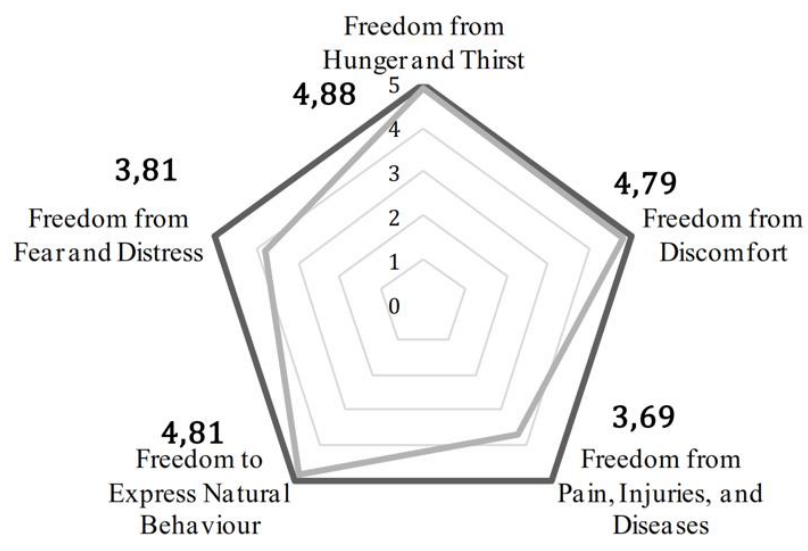

Figure 1. Animal welfare score in Barumun Nagari Wildlife Sanctuary, North Sumatra, Indonesia

Feed and drink are indeed essential for animal life. The tigers at BNWS get good enough food to eat and drink with good quality because they are fed every day. However, the determination of the amount of feed has not been carried out based on body weight and daily activities of the tigers. The tigers are fed with whole wild boar which had been cut into 4 parts and cleaned from its entrails. Sometimes they are fed with a whole chicken. Thus, feeding in BNWS automatically varies from meat to bone. The female tiger, Gadis, and her two cubs get $10 \mathrm{Kg}$ of meat/day while the male tiger, Monang, gets $6 \mathrm{Kg}$ of meat/day, with a one-day feeding schedule, following the guides of GFAS (2018) and AZA (2016) which state that tigers are fed once a day. The feed is given every day (for 6 consecutive days) with a one-day fasting break. This interlude aims to familiarize the tigers with fasting since when they are released to the wild, they will not necessarily get food every day. The implementation of fasting times for tigers at BNWS has been supported by global tiger conservation and rehabilitation institutions.

The study found a difference made by the manager regarding the presentation of feed. At BNWS, the feed is provided to tigers without using any bucket or bowl. This is intended to familiarize the tigers with conditions in their natural habitat. However, according to GFAS (2018) and AZA (2016), food items should be placed in stainless steel buckets/bowls or on easily sanitized to minimize contamination from urine and stool. This standard applies to zoos where the floors are made of cement, so the possibility of spreading bacteria is high, while in BNWS, the enclosure's floor is natural ground. However, this issue needs further research.

The second-best score was obtained in the parameter of 'freedom to express natural behavior' (4.81). The management of 'Freedom to Express Natural Behavior' aspects can be seen from the adequacy of space and enclosure, security and enrichment facilities. Enclosures are designed to allow the tigers to move freely and interact with the environment. BNWS provides sufficient space for the tigers to behave naturally, although improvements are 
still needed on enrichment programs. Referring to AZA (2016), the development of enrichment initiatives should focus on promoting species-appropriate behaviors in tigers and providing them with choice and control within their exhibit environment. With each of the items on the following list, a natural behavior such as stalking, hunting, playing or foraging should be encouraged.

However, according to Mellen et al. (1998) providing opportunities for tigers to behave naturally like in their habitat is difficult to do in a cage. Nevertheless, Shepherdson et al. (1993) and Shepherdson and Mellen (1998), explain that animal keeper can carry out creativity and take innovative approaches to provide opportunities for tigers to behave naturally such as stalking, pouncing, running, chasing, climbing and marking scents.

The tigers at the BNWS sanctuary are supported with good facilities, so they can behave naturally and move freely. The adaptation enclosure is located in open space allowing other animals e.g. pigeons and doves to fly into the cage, providing a good opportunity for tigers to practice hunting.

The enclosure is also equipped with a cave for hiding, and wooden blocks for scratching. A pool with water flowing directly from mountain springs is available in the adaptation enclosure as a source of drinking water, as well as for practicing catching the fish. The pool is designed with a drying and cleaning system easily operated from outside the enclosure, making it easier to clean and fill the water. This is following GFAS (2018) which states that permanent pool structures must have an adequate filtration system to maintain water quality parameters or designed to allow easy draining, cleaning and refilling at appropriate intervals to ensure that the water remains potable. The sanctuary is also equipped with shelter and shade trees. The shelter serves as a shelter for the animals to prevent excessive energy expenditure in animals, and protects the animals from bad weather, and predators (Bolen and Robinson 2003).

The third score was found in 'freedom from discomfort' parameter (4.79). The management on 'freedom from discomfort' can be seen from the type of enclosure, the adequacy of space and enclosure completeness, temperature and humidity, construction, and the cleanliness of the enclosure. BNWS provides a fairly large enclosure, both for quarantine (indoor) and the adaptation (outdoor) enclosure. BNWS provides a $15 \mathrm{~m}^{2}$-quarantine enclosure (3 $\mathrm{m} \times 5 \mathrm{~m}$ ), while the outdoor enclosure (for adaption) is $1,000 \mathrm{~m} 2$ (25 m x $40 \mathrm{~m}$ ). Referring to GFAS (2018), the minimum size of an enclosure for a pair of tigers is 55.7 $\mathrm{m}^{2}$. The outdoor enclosure provides 5 meter-high fences and has exceeded the standards set by GFAS (2018), which is 3.7 meters for medium and large tigers. To ensure the comfort and health of the tigers, the quarantine enclosure is cleaned daily, while the adaptation enclosure is cleaned every three days. The manager does not use disinfectants in the cleaning process, even though this is very important to do. GFAS (2018) and AZA (2016), emphasize that each enclosure must be cleaned using a disinfectant to avoid zoonosis.

At BNWS the tiger enclosure is designed in such a way to avoid the existence of angular walls, to allows the tiger to move freely. This is following GFAS (2018), which explains that felids need to be provided access to as many areas of the enclosures as possible, except during staff maintenance activities, unless security concerns dictate otherwise. All enclosures are interconnected without creating 'dead ends' to allow for freedom of movement of subordinate individuals

The 'freedom from fear and distress' followed the previous parameter with a score of 3.81. The management of 'freedom from fear and distress' aspects can be assessed from the number and competency of the animal keepers, handling of newly arrived tigers, signs of behavior and efforts made in dealing with stressed animals.GFAS (2018) states a sanctuary must have at least one animal keeper and a reserve staff trained in all aspects of tiger protection and behavior, to ensure that experienced animal keepers are always available any time when there are staff changes. However, this condition is not in line with the findings in this study, where the BNWS only has one animal keeper, without any reserve staff if he is unavailable. Moreover, the animal keeper has never been trained in aspects of biology and tiger behavior. Nevertheless, he is quite reliable and dexterous in caring for and providing tiger needs at the BNWS sanctuary.

The lowest score is indicated by the parameter 'freedom from pain, injury and diseases' (3.69). Management of aspects of 'free from pain, injury, and disease' can be observed from animal health, frequency of medical checks, health records, availability of health workers, medical facilities and handling of sick animals. The tiger health can be achieved by cleaning cages, food receptacles, and waste management. A simple standard of cleanliness in the sanctuary environment is to drain the pond and spray the enclosure with disinfectants regularly. Despite getting the value of 3.69, this parameter was considered 'Fair', however, this needs to be a concern for managers, especially in ensuring that tiger health and safety is always a priority in management. Biosafety is an important issue to be prioritized in managing a sanctuary. BNWS needs to implement the procedure for veterinarians and animal keepers to wear Personal Safety Equipment (PPE) in handling animals such as feeding, health checks, and enclosure maintenance. The procedure is highly important to be considered by the manager to avoid zoonosis.

According to GFAS (2018), a physical examination must be carried out every year, including body weight, temperature, pulse, breathing, nails, footwear, teeth with special attention to cracked canines, and the entire body for abscesses and lacerations. Similarly, a fecal examination must be applied every three months to determine whether there are parasites in the body. Unfortunately, BNWS has not carried out routine and in-depth health examination for the tigers due to the lack of facilities and number of veterinarians. The examination was conducted by simply observing tiger behavior and when the tiger looked sick. This should be a concern for the manager. GFAS (2018) explains that parasite examination for a captive animal is a mandatory procedure. However, BNWS has not implemented this yet, since it requires the availability of 
laboratories, and the examination requires high cost and it becomes a constraint for BNWS in meeting the standard.

Another important thing to be considered is the absence of animal hospital near BNWS or in the closest city, Padang Sidimpuan, which can provide medical services any time an emergency occurs on the tiger. Consequently, if an accident happens and cannot be handled by the BNWS manager, the tiger must be evacuated very far to the city of Medan, at a distance of $380 \mathrm{~km}$, or Padang, $390 \mathrm{~km}$. This causes a very high risk to the safety of the tigers. This certainly needs to be a concern by the government.

The determination of animal welfare implementation may refer to the standard set by PHKA (2011). This standard is provided for general conservation organizations such as the zoo. However, because its management is somewhat similar to the sanctuary, the researcher applied it to the sanctuary. The value of Animal Welfare Implementation can be seen in Table 3.

The high of the average score (89.13) shows the achievement of the implementation of animal welfare at BNWS is very good, according to PHKA (2011). Nevertheless, several things need to be improved in managing animal welfare at BNWS. Some of these are following the instructions directed by GFAS and AZA, namely: Considering the results of analyses, the following recommendations are given for sanctuary managers to improve the animal welfare: (i) Providing complete medical requirements including clinic facility equipment based on minimum standards of animal clinics. (ii) Implementing biosafety and biosecurity systems and principles to avoid bacterial transmission from animals to humans and the environment, and vice versa. (iii) Adjusting the quality and quantity control of feed according to body weight and age and animal activity. (iv) Recording the tigers' daily behaviors that enable the managers to observe their developments and behavior and determine when they are ready to be moved to the next stage. (v) Implementing a well-planned enrichment program where every progress is recorded in detail. (vi) Providing more than one animal keeper so when the keeper is unavailable, a substitute animal keeper is always available at all times.

Since the regulation on animal welfare in sanctuary particularly for tigers, has not been available to date, BNWS has implemented animal welfare management based on input from partners and experience over the past few years. Hence, BNWS needs a clearer direction to ensure that the implementation of animal welfare is carried out properly, according to the needs and behavior of tigers.

The guideline should be officially published by the government to avoid differences of opinions among sanctuary managers, scientists or conservationists involved in tiger conservation. Therefore, the government needs to immediately formulate a policy to be a direction for sanctuaries managers in implementing animal welfare. The guideline may be based on the existing DG PHKA Regulation Number P.6/IV-SET/2011. The guideline may then adopt some important elements of GFAS and AZA, as well as the latest research results, concerning the behavior of the Sumatran tiger.
Table 3. The value of animal welfare implementation in Barumun Nagari Wildlife Sanctuary, North Sumatra, Indonesia

\begin{tabular}{lllc}
\hline \multicolumn{1}{c}{ Parameter } & Weight & Score & IWP Value \\
\hline $\begin{array}{l}\text { Freedom from hunger and } \\
\text { thirst }\end{array}$ & 30 & 4.88 & 146.54 \\
$\begin{array}{l}\text { Freedom from discomfort } \\
\begin{array}{l}\text { Freedom from pain, injuries } \\
\text { and diseases }\end{array}\end{array}$ & 20 & 4.79 & 95.83 \\
$\begin{array}{l}\text { Freedom to express natural } \\
\text { behavior }\end{array}$ & 15 & 3.69 & 73.89 \\
$\begin{array}{l}\text { Freedom from fear and distress } \\
\text { Total individual parameter weight value }\end{array}$ & 15 & 3.81 & 72.19 \\
\begin{tabular}{l} 
Implementation achievement value \\
\hline
\end{tabular} & & 57.19 \\
\end{tabular}

Table 4. Improvements need on animal welfare management in Barumun Nagari Wildlife Sanctuary, North Sumatra, Indonesia

\begin{tabular}{|c|c|c|}
\hline $\begin{array}{c}\text { Animal welfare } \\
\text { parameters }\end{array}$ & SCORE & AZA / GFAS \\
\hline $\begin{array}{l}\text { Freedom from } \\
\text { hunger and thirst }\end{array}$ & $\begin{array}{l}\text { Very good } \\
(4.88)\end{array}$ & $\begin{array}{l}\text { The amount of feed should } \\
\text { be determined based on the } \\
\text { age and bodyweight of the } \\
\text { tiger. }\end{array}$ \\
\hline $\begin{array}{l}\text { Freedom from } \\
\text { discomfort }\end{array}$ & $\begin{array}{l}\text { Very good } \\
(4.79)\end{array}$ & $\begin{array}{l}\text { Feeding areas, automatic } \\
\text { water devices, water, and } \\
\text { food containers should be } \\
\text { cleaned and disinfected } \\
\text { daily }\end{array}$ \\
\hline $\begin{array}{l}\text { Freedom from pain, } \\
\text { injuries, and } \\
\text { diseases }\end{array}$ & $\begin{array}{l}\text { Fair } \\
(3.69)\end{array}$ & $\begin{array}{l}\text { Regular fecal examinations } \\
\text { should be done to look for } \\
\text { parasites, protozoa, and } \\
\text { bacteria. }\end{array}$ \\
\hline $\begin{array}{l}\text { Freedom to express } \\
\text { natural behavior }\end{array}$ & $\begin{array}{l}\text { Very good } \\
(4.81)\end{array}$ & $\begin{array}{l}\text { The good management of } \\
\text { this parameter should be } \\
\text { maintained although there } \\
\text { are no clear policies or } \\
\text { guidelines regarding the } \\
\text { management of sanctuaries } \\
\text { in Indonesia. }\end{array}$ \\
\hline $\begin{array}{l}\text { Freedom from fear } \\
\text { and distress }\end{array}$ & $\begin{array}{l}\text { Fair } \\
(3.69)\end{array}$ & $\begin{array}{l}\text { Enrichment programs } \\
\text { should be conducted to } \\
\text { promote species-appropriate } \\
\text { behavioral opportunities and } \\
\text { ensure the captive felids' } \\
\text { psychological well-being }\end{array}$ \\
\hline
\end{tabular}

Seeing the increasing trend of human-tiger conflict, therefore, optimizing animal handling at the sanctuary is highly important, especially for recovery programs and preparation for release of tigers to their habitat. Enrichment programs should also be enhanced to ensure the animals have a good ability to adapt, compete and survive when they are released. Enrichment can also be regarded as an effort to minimize the possibility of tigers being involved again in conflict with humans. BNWS and other sanctuaries should be fully supported by the government related to the management of their animals and also the support from academic institutions to conduct research that is applicable in improving animal welfare and tiger 
reintroduction program. This study concluded that BNWS had made good efforts to fulfill animal welfare at the sanctuary although some improvements still have to be made.

\section{ACKNOWLEDGEMENTS}

We would like to thank the management of Barumun Nagari Wildlife Sanctuary for such great support, providing useful information as well as giving full access to research the sanctuary area. We would also like to thank our colleagues at the Centre for Natural Resource Conservation of North Sumatra for providing permit and insight, and the Barumun Consortium and Simpul Indonesia for great assistance in this research.

\section{REFERENCES}

AZA Tiger Species Survival Plan®. 2016. Tiger Care Manual. Association of Zoos and Aquariums, Silver Spring, MD.

BBC [Internet]. 2016. Harimau Sumatera mati terjerat dalam kondisi hamil, dua bayinya ikut mati. Indonesia: News Indonesia. [June 1, 2019]. [Indonesian]

BBKSDA North Sumatra. 2019. Internal Report on Human-Tiger Conflict Cases at North Sumatra Area from 2007-2019. Medan, North Sumatra.

Bolen EG, Robinson LW. 2003. Wildlife Management Ecology and Management. 5th ed. Prentice-Hall, New Jersey, USA.

Direktorat Jenderal Pelestarian Hutan dan Konservasi Alam. 2011. Peraturan Direktur Jenderal Pelestarian Hutan dan Konservasi Alam (PHKA) No. P.6/IV-SET/2011 Tentang Pedoman Etika dan Kesejahteraan Satwa di Lembaga Konservasi. (Director General Regulation of Forest Conservation and Nature Conservation (PHKA) No. P.6 / IV-SET / 2011 on The Guidelines for Ethics and Welfare of
Animals in Conservation Institutions.) ID: Direktorat Jenderal Pelestarian Hutan dan Konservasi Alam, Jakarta. [Indonesian]

Fraser AF, Broom DM. 1990. Farm Anima von Holst D.1986. Vegetative and somatic components of Behaviour and Welfare. Saunders, New York.

Global Federation of Animal Sanctuaries. 2018. Standards for Felid Sanctuaries, Washington, DC.

Goodrich JM, Seryodkin I, Miquelle DG, Bereznuk SL. 2010. Conflicts between Amur tiger and humans in the Russian Far East. Biol Conserv 144: 584-592.

Kartika EC. 2017. Spatio-Temporal Patterns of Human Tiger Conflicts in Sumatra 2001-2016. Direktorat KKH-KLHK. Jakarta. [Indonesian]

Mellen JD, Hayes M, Sheperdson D. 1998. Captive environments for small felids. In: Sheperdson D, Mellen JD, Hutchins M (eds). Second Nature. Environmental enrichment for captive animals. Smithsonian Institution, Washington, D.C.

Mellor DJ, Beausoleil NJ. 2015. Extending the "Five Domains" model for animal welfare assessment to incorporate positive welfare states. Anim Welfare 24: 241-253.

Nyhus PJ, Tilson R. 2004. Characterizing human-tiger conflict in Sumatra, Indonesia: Implications for conservation. Oryx 38: 68-74.

OIE. World Organization for Animal Health. 2009. Terrestrial Animal Health Code. OIE, Paris.

Rudijanta TN, Sugardjito J. 2009. Assessment and management options of human-tiger conflicts in Kerinci Seblat National Park, Sumatra, Indonesia. Mammals Stud 34: 141-54.

Sanderson E, Forrest J, Loucks C. 2006. Setting Priorities for the Conservation and Recovery of Wild Tigers: 2005-2015: The Technical Assessment. WCS, WWF, Smithsonian, and NFWF-STF, New York and Washington, DC.

Shepherdson DJ, CarlsteadK, Mellen JD.SeidenstickerJ. 1993. The influence of food presentation on the behaviour of small cats in confined environments. Zoo Biol 12: 203-216.

Shepherdson DJ, Mellen JD, Hutchins M. 1998. Second Nature: Environmental Enrichment for Captive Animals. Smithsonian Institution Press, Washington, DC.

Soehartono T, Wibisono HT, Sunarto, Martyr D, Susilo HD, Maddox T, Priatna D. 2007. Strategi dan Rencana Aksi Konservasi Harimau Sumatera (Panthera tigris sumatrae). Direktorat Perlindungan Hutan Dan Konservasi Alam, Departemen Kehutanan, Jakarta. [Indonesian]

Triastuti I. 2015. Philosophy study on animal welfare in relation to management in conservation institutions. Yustisi 1 (1): 6-10. [Indonesian] 